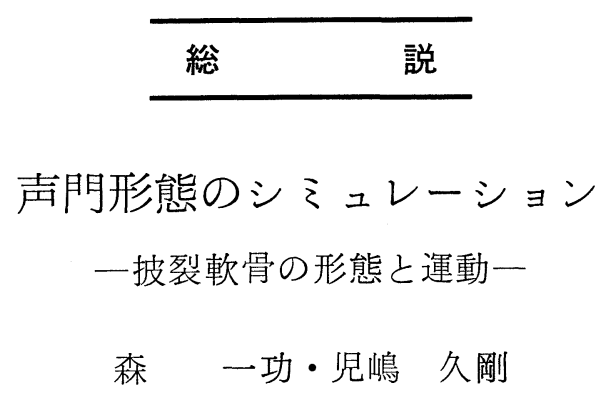

\title{
Computer Simulation of Movements of Arytenoid Cartilages
}

\author{
Kazunori Mori and Hisayoshi Kojima \\ (Kyoto University)
}

Three-dimensional computer graphics and computer simulation should be useful to clarify the relationship between the three-dimensional movement of the arytenoid cartilage and the contraction power of the internal laryngeal muscles. The literature is reviewed in an attempt to clarify this relationship.

It is necessary to identify both the three-dimensional structure of the crico-arytenoid joint and the direction of the internal laryngeal muscle fibers by observation of the threedimensional computer graphics reconstructed from cross sections of the larynx. It is also necessary to draw the glottal shape transformed by electrical stimulation, using computer graphics, and to calculate the contraction power of the laryngeal muscles, using three-dimensional vector analysis. Then it will be possible to simulate the relationship between the condition of the internal laryngeal muscles and the position of the arytenoid cartilage.

The computer simulation of the glottal shape should make it possible to know the condition of the internal laryngeal muscles in phonation.

Key words: larynx, computer, simulation, graphics

緒言

音声学における基本的な命題である発声機構

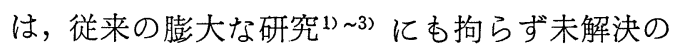
部分がなお残されている。乙の解明の一助とし て，披裂軟骨の 3 次元的な動き之内喉頭筋との 関係から声門形態の変化の機構を明らかにして おく必要があると思われる。乙の輪状披裂関節 での披裂軟骨の運動は, 主として, 関節面の形 状と付着する筋の走行と筋力で規定されるが, これらのデータの総合, 解析には, 3 次元べク
トルの解析的な検討, なかであコンピューター ・グラフィクスやシミュレーションによる方法 が有用と思われる．本稿ではコンピューター・ グラフィクスとシミュレーションによる声門形 態の解明に必要な情報, 従来の研究につけ加え るべき点などを文献的に整理し，声門形態の解 明の手がかりにしようとした。

\section{文献的考察}

3 次元的な披裂軟骨の動きをシミュレートす るには，1）披裂軟骨と輪状披裂関節の形態之 
可動範囲 (ベクトルの作用点)，2）披裂軟骨へ 付着する内喉頭筋群の筋走行の方向（筋収縮べ クトルの方向)，3）内喉頭筋群の筋収縮力 (ベ クトルの大きさ), の 3 つが必要と思われる. そ れぞれのデータが得られたときにどの程度のシ ミュレーションが可能かを，以下に文献的に考 察した。

1）ベクトルの作用点について

ヒトの輪状披裂関節は円筒形であることが従 来指摘()されており, その後, 詳細な計測 ${ }^{5) ~ 7) ~}$ が行なわれてきた。これらの報告で一致するこ とは, 輪状軟骨の関節面は縦長（縦軸）のほぼ 半円筒形をしているとと，披裂軟骨の関節面は ほぼ円形とも言える凹面で，関節面の横径は披 裂軟骨の方が輪状軟骨より長く，縦径は逆に輪 状軟骨の方が披裂軟骨より長いととである ${ }^{1)}$.

一方，輪状披裂関節の形態加ら披裂軟骨の運動 を推察した報告4) 578)9》では，披裂軟骨の運動は 輪状軟骨の関節面の縦軸回りの回転, 縦軸に平 行な滑行からなり，後輪状披裂勒帯の回りにも 動くとされる.

このように，披裂軟骨の動きは関節面での制 約が大きいため，形態だけから披裂軟骨の動き を推定するととは比較的容易と思われる. コン ピューター・グラフィクスの手技を用いれば， 披裂軟骨が輪状披裂関節の関節面を滑って変位 したときの筋突起の位置は容易に求めることが できるからである，そのためには，関節面の形 態を 3 次元的に確認し, 関節の長さや弯曲度を 測定し，さらに関節カプセルの長さを考慮する 必要がある.これには喉頭の大切片からのコ ンピューターによる 3 次元構筑が必須と思わ れる.

2) ベクトルの方向について

ヒト内喉頭筋の筋走行から声帯位を推察する 従来の報告 $\left.{ }^{10} 111\right)$ では, 内筋, 側筋, 横筋は声門 閉鎖筋, 内筋は声帯を内転かつ短縮, 側筋は声 帯突起を下降内旋，横筋は声帯軟骨部を内旋閉 鎖するとされ，前述の輪状披裂関節の形態から の推測とほぼ一致している。乙れらの報告は筋
収縮ベクトルの方向をほぼ明らかにしたもので あるが，筋繊維の複雑な走行を詳細に見るのに 屯喉頭の大切片からの 3 次元的再構成が有用で あり，その後， 3 次元の XYZ データとして定 量化する必要がある．関節の形態のデータにと のデータを併せることで，内喉頭筋が収縮した 時の披裂軟骨の変位の方向, 筋突起の変位の方 向を推定することができる，乙れにより，例え ば内筋を構成する声帯筋，外甲状披裂筋の声門 形態への関与の違いむ， ある程度推定するとと ができると思われる。

なお, 前筋之後筋については, 筋電図学的研 究12) 18) では後筋は単なる声門開大筋ではなく 調音機能むあるとされている。 また，筋繊維の 走行の観察 ${ }^{192}$ 20) などから，後筋は披裂軟骨を輪 状軟骨上に固定して声帯の緊張を助長するとさ れている．声門閉鎖時には，後筋ベクトルは筋 弛緩時の一定の緊張度だけを持っているのでは ないと考えられる．また，前筋は，筋電図学的 検討 $\left.\left.{ }^{122} 21\right) \sim 24\right)$ では声帯の位置によっては声門開 大筋としても働く声帯緊張筋とされる．前筋は 内喉頭筋によって規定される声帯位を微妙に修 飾する作用を持つと考えられる。 そのため，コ ンピューター・シミュレーションの際, ての後 筋, 前筋も考慮する必要があると思われる.

さて，摘出ヒト喉頭の筋起始部にかけた糸を ひいて披裂軟骨の動きを 3 次元的に計測する と，披裂軟骨は輪状披裂関節の縦軸の回りに回 転することが報告 $\left.{ }^{252} 26\right)$ されている．披裂軟骨は 回転運動と滑り運動で変位するために筋収縮に よるベクトルは最後まで一定の方向を保つとは 限らない，そのため，系による率引実験は生体 での筋収縮をそのままは表わさないという問題 がある。しかしコンピューター・シミュレーシ ョンでは披裂軟骨の変位にとむない筋収縮ベク トルの方向が計算できるので，その点の解決は できると考えられる.

しかし，乙こまでの段階ではあくまであ関節 と筋の形態からのシミュレーションであり，生 体での声門運動との間にはずれがある. 
3）ベクトルの大きさについて

披裂軟骨の変位は, 主に各内喉頭筋の収縮力 のバランスの上に成立しており，乙の収縮力の 相対的な比（ratio）だけでもわかれば，披裂軟 骨の動きはかなり明らかになると考えられる。

こうして関節の形態と筋走行のデータに収縮力 のデータを併せれば，生体での声閒運動のシミ ユレーションに一歩近づくととができる，ての 収縮力あるいはその相対的な比を調べるには， (1)支配神経あるいは喉頭筋の電気刺激で声門形 態の変化を調べ，乙れから逆に筋収縮ベクトル を求める方法, (2)電気刺激による収縮ベクトル を直接計測する方法，がある，また，筋自体は 弛緩時にあ一定の緊張度を有するわけであるが， この緊張度は複数筋の同時刺激によりある程度 求め得ると思われる.

(1)声門形態からの逆算

内喉頭筋が収縮した時の声門形態を，関節の 形態と筋走行からのシミュレーションによる声 門形態と比較することで，筋収縮ベクトルの相 対的な比を求めることができる.

従来, 各内喉頭筋や支配神経を直接刺激して 内喉頭筋と声門形態との関係を見た報告22) 23) 27) 〜32) は声門の平面的分析で 3 次元的な検討はさ れていなかったが，最近，声帯の長さ，厚み， 内転外転の程度, 声帯レベル, 声門面積の変化 についての定量的な報告33334) が見られるよう になった. 今後, 3 次元座標值で表わすとと で，逆算による収縮力の比を求めるデータとし て使えると考えられる。

(2)筋力そのものの計測

電気刺激での筋収縮力は，喉頭筋に糸をかけ

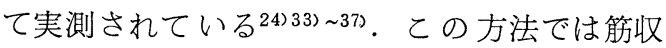
縮ベクトルの大きさを直接求めることができ, そのままデータとして使用が可能である.

また，筋力そのものではなく，神経の電気刺 激で声帯の水平方向の閉鎖開大力を測定した報 告 ${ }^{38} 3{ }^{395}$ あある. 声門閉鎖力とは，声帯上面のな す平面上にあってかつ声帯縁に直角な方向のべ クトルと解釈でき，ベクトルの大きさを実際の
值で表わしたものと考えられる．乙れは内喉頭 筋の筋収縮力ベクトルがどの程度の大きさかを 換算できるデータとなりうる.

しかし, 声門形態加ら逆算する方法, 直接計 測する方法の 2 つとも，電気刺激は非生理的で あるとと, 刺激頻度と筋収縮力とは比例しない ことから，そのデータをただちに生体での声門 運動に結びつけるととは難しいと思われる.

\section{まとめと今後の展望}

筋収縮ベクトルの作用点（披裂軟骨）の移動 の方向と可動範囲, 及びベクトルの方向は既に 定性的に明らかにされており，系での牽引など のシミュレーションが試みられている。また， 内喉頭筋の収縮による声門形態の変化は 3 次元 的にあ定量化されつつある. しかし，乙れらの データだけからでは内喉頭筋の収縮力と声門形 態との関係を明らかにすることはできない。乙 れは，1. 輪状披裂関節での動きが複雑なと と，2. 披裂軟骨の変位の方向はどの喉頭筋の

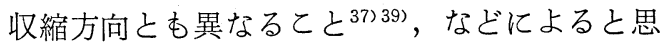
われる. この解明はべクトル解析的検討により 可能と思われ，そのためにはコンピューターに よるグラフィクスとシミュレーションが有用と 考えられる. 今後, 声門運動のシミュレーショ ンを行なっていく上で必要な手続きは次の 2 点 である. 1. 輪状披裂関節と筋走行の定量的検 討: 喉頭の大切片からのコンピューター・グラ フィクスを用いた 3 次元構築. 2. 各内喉頭筋 収縮時の声門形態の 3 次元的把握 : 電気刺激な どによる声門形態の変化をコンピューター・グ ラフィクスで正確に表わす．更にてのデータか ら各内喉頭筋の収縮力をべクトル解析的な方法 で求め, 各内喉頭筋の収縮力の変化之披裂軟骨 の変位との関係を推定する。また，筋収縮力あ るいは声門閉鎖圧を実測すれば，声帯縁に平行 なベクトルの大きさ（このベクトルは声带緊張 度を表わす一つのパラメータと思われる）も定 量化できると考えられる.

しかし，電気刺激のデータと生体での声門運 動とを直接結びつけることはできず，乙の解決 
は今後の課題である.

以上述べてきたように，声門形態のシミュレ ーションは発声機構解明の一つの手がかりにな ると思われる。すなわち，声門形態の解明で内 喉頭筋群の働きはより明確になり，発声時の内 喉頭筋群の収縮力などの解明に役立つと考えら れる。また，上述の声帯緊張度の定量化によ り，各内喉頭筋と音声のピッチとの関係など喉 頭の基礎的問題の解明の手段となり得る。 ま た, 臨床的には, 声門の形態加ら内喉頭筋の状 態（筋力，萎縮度，悪性腫湯の浸潤度など）の 推測が可能になるものと思われる。

稿を終えるに当たり，御校閲をいただいた本庄 䉷 教授に深謝致します。

\section{参考文献}

1) 広戸幾一郎：発声機構の面より見た喉頭の病態生 理. 耳鼻臨床 $59: 229 \sim 291,1966$.

2 ) 一色信彦: 喉頭機能外科. 京都大学医学部耳鼻科 同空会, 1977.

3 ）平野 実: 音声外科の基礎之臨床. 耳鼻 21 : 239 440, 1975.

4) Snell C: On the function of the crico-arytenoid joints in the movements of the vocal cords. Proc Kon Nederl Acad Wet 50:1370 1381, 1947.

5) Maue WM and Dickson DR : Cartilages and ligaments of the adult human larynx. Arch Otolaryngol $94:$ 432 439, 1971.

6 ) 平本道昭 : 喉頭機能外科の解剖学的基礎に関する 研究. 耳鼻臨床 $70: 177 \sim 197,1977$.

7 ）佐藤公則：喉頭の立体解剖. 耳鼻 $33: 153 \sim 182$, 1987.

8 ) 山下喜六 : 喉頭関節の機能解剖学的研究. 熊本医 学会雑誌 $27: 83 \sim 94,1953$.

9 ) von Leden $\mathrm{H}$ and Moore $\mathrm{P}:$ The mechanics of the cricoarytenoid joint. Arch Otolaryngol 73 : 541 550, 1961.

10）万城目忠男 : 日本人の喉頭筋に関する解剖学的研 究. 日耳鼻 $62: 1890 \sim 1900,1959$.

11）高瀬晴郎：哺乳動物内喉頭筋および喉頭関節の比 較解剖生理学的研究. 耳鼻 $10: 18 \sim 58,1964$.
12) Andersen KF : Electromyographic investigation of intrinsic laryngeal muscles of humans. Acta Physio Scan $41: 140 ; 1 \sim 148,1957$.

13）沢島政行, 佐藤正夫, 船坂宗太郎, 他 : 喉頭筋の 筋電図およびその臨床的応用. 日耳鼻 $61: 1357$ $\sim 1364,1958$.

14）浦田敬造 : 発声時の人の内喉頭筋の筋電図学的研 究. 耳鼻臨床 53 : 811 841, 1960.

15) Hiroto I, Hirano M, Toyozumi $Y$, et al : Electromyographic investigation of the intrinsic laryngeal muscles related to speech sounds. Ann Otol $76: 861 \sim 871,1967$.

16）平野 実：起声時の喉頭調節敒関する筋電図的研 究. 日耳鼻 $74: 1572 \sim 1579 ， 1971$.

17）広瀬 肇：起声時における内喉頭筋の活動様式. 日耳鼻 $75: 981 \sim 988,1972$.

18）広瀬 肇：後輪状披裂筋の機能（特に発話に関連 した機能を中心として).耳鼻 $19: 711 〜 723$ ， 1973.

19）村上 泰：後輪状披裂筋反射とその生理的意義. 日耳鼻 $74: 1263 \sim 1270 ， 1971$.

20）村上 泰: 喉頭の臨床解剖と生理. 日耳鼻 76 : 911 914, 1973.

21）広瀬 肇：声門閉鎖筋の機能分化. 日耳鼻 77 : 46〜 57, 1974.

22）中村文雄, 植田 豊, 竹之内智, 他：喉頭神経の 電気的刺激による声帯の運動. 日耳鼻 $64: 380$, 1961.

23）広戸幾一郎：発声機能面よりみた喉頭の病態生 理. 日耳鼻 $69: 2097 \sim 2106,1966$.

24）牛島達次郎：喉頭筋の機械的収縮特性に関する実 験的研究. 日耳鼻 $71: 1494 \sim 1509 ， 1968$.

25) Frable MA : Computation of motion at the cricothyroid joint. Arch Otolaryngol $73: 73 \sim$ 78, 1961.

26）清川兼輔 : 内喉頭筋のはたらきと声門の形態（ヒ トの摘出喉頭による実験的研究). 耳鼻 33 : 183 217, 1987.

27) Brewer DW and Dana ST : Investigation in laryngeal physiology; the canine larynx. Ann Otol $72: 1060 \sim 1075,1963$.

28）竹之内智：喉頭神経刺激による声門の運動に関す る研究.耳鼻臨床 $56: 398 \sim 420,1963$.

29) Williams AF : The nerve supply of the laryngeal 
muscles. J Laryngol $65: 343,1951$.

30) Capps FCW : Abductor paralysis in theory and practice since Semon. J Laryngol $71: 1,1958$.

31) Kotby MN and Haugen LK : Attempts at evaluation of the function of various laryngeal muscles in the light of muscles and nerve stimulation experiments in man. Acta Otolaryngol $70: 419 \sim 427,1970$.

32）岩村 忍：喉頭筋の機能区分. 音声言語 $15: 77$ $\sim 78,1974$.

33）小池裕一, 平野 実, 森尾倫弘, 他: 内喉頭筋の 機能(声門及び声門形態の変化に関して). 日耳鼻 $78: 1250 \sim 1257,1975$.

34）森尾倫弘：内喉頭筋の機能（特に声門部の形態的 変化に関する実験的研究). 耳鼻臨床 $22: 143$ 179, 1976.

35) Hast MH : Mechanical properties of the crico- thyroid muscles. Laryngoscope $76: 537 \sim 548$, 1966.

36) Hast $\mathrm{MH}:$ Mechanical properties of the vocal fold muscle. Prac Oto-Rhino-Laryngol 29 : 53 56, 1967.

37）佐藤文彦, 矢野原邦生, 竹之内智, 他 : 内喉頭筋 収縮と声門の形態ならびに力学. 気食 $33: 302$ ح308, 1982.

38）村上 泰：声帯運動と声帯位（神経筋生理の立場 加). 耳鼻 $19: 64 \sim 78,1973$.

39）佐藤文彦, 矢野原邦生, 竹之内智, 他 : 内喉頭筋 の収縮特性と声門運動. 日耳鼻 85 : 951 956, 1982.

$\left(\begin{array}{l}\text { 原稿採択 : 昭和63年11月 } 5 \text { 日 } \\ \text { 別刷請求先 : 森 一功 } \\ \text { 平606 京都市左京区聖護院川原町54 } \\ \text { 京都大学医学部耳鼻咽喉科学教室 }\end{array}\right)$

